\title{
O SISTEMA DE ALERTA PRECOCE NA UNIÃO EUROPEIA
}

\author{
THE EARLY WARNING SYSTEM IN THE EUROPEAN UNION
}

\section{RESUMO}

O objetivo do presente artigo é analisar o Sistema de Alerta Precoce, o qual foi consagrado com a finalidade de instituir um controle sobre a aplicação do princípio da subsidiariedade na União Europeia. Inicialmente, investigamos o significado das disposições constantes no Protocolo $\mathrm{n}^{\circ} 2$ do Tratado da União Europeia. Na segunda parte do trabalho, averiguamos se 0 procedimento estabelecido foi construído de forma apropriada à consecução de seus objetivos. Concluímos que o arranjo essencialmente procedimental adotado é adequado à natureza essencialmente política do princípio da subsidiariedade, pois ele conduz as instituições legislativas a realizar um exame detalhado antes de concluírem se a ação no nível europeu é requerida.

Palavras-chave: princípio da subsidiariedade; Sistema de Alerta Precoce; União Europeia.

\begin{abstract}
The aim of this paper is to analyze the Early Warning System, which was established with the purpose of establishing control over the application of the principle of subsidiarity in the European Union. Initially, we investigated the meaning of the provisions of Protocol 2 of the Treaty on European Union. In the second part of the work, we examine if the procedure established was built appropriately to achieve its goals. We conclude that the essentially procedural arrangement adopted is suitable for the political nature of the principle of subsidiarity, as it leads the legislative institutions to undertake a detailed examination before concluding that the action at European level is required.
\end{abstract}

Keywords: principle of subsidiarity; Early Warning System; European Union.

\section{SUMÁRIO}

INTRODUÇÃO; 10 PROTOCOLO NN 2 DO TRATADO DA UNIÃO EUROPEIA; 1.1 Considerações Gerais; 1.1.1 Transmissão das propostas aos parlamentos nacionais; 1.1.2 Limiares de votação; 1.1.3 Prazo de oito semanas; 1.2 Propostas de emenda; 1.3 Procedimento do cartão vermelho; 1.4 Controle da proporcionalidade; 2 OBJETIVOS DO SISTEMA DE ALERTA PRECOCE; 2.1 Observância do princípio da subsidiariedade; 2.2 Redução do déficit democrático; CONCLUSÃO; REFERÊNCIAS. 


\section{INTRODUÇÃO}

As competências da União Europeia foram ampliadas em cada uma das reformas de seus tratados constitutivos. Cada vez mais, as decisões que afetam diretamente a vida quotidiana dos cidadãos europeus passaram a ser tomadas pelas instituições europeias, e os parlamentos nacionais perderam uma parte considerável do seu poder para estas instituições. Esse fato gerou uma grande inquietação entre os governos e os cidadãos em geral, tendo em vista a dilatação constante do poder de intervenção da União em domínios que tradicionalmente eram objeto do exercício de competências exclusivas dos órgãos nacionais. Com a finalidade de conter a expansão das competências comunitárias e de aquietar o temor de um crescente e correlativo esvaziamento das competências dos Estados, o Tratado de Lisboa consagrou um novo mecanismo de controle político ex ante, chamado Sistema de Alerta Precoce (Early Warning System) que possibilita aos parlamentos nacionais apontarem violações ao princípio da subsidiariedade nas propostas de atos legislativos e oporem determinados obstáculos à adoção dessas propostas. Esse tratado consagrou, outrossim, um nova definição do princípio da subsidiariedade. Conforme esse princípio, agora previsto no artigo $5^{\circ}(3)$ do Tratado da União Europeia, nos domínios que não sejam da sua competência exclusiva, a União intervém apenas se e na medida em que os objetivos da ação considerada não possam ser suficientemente alcançados pelos Estadosmembros, podendo, contudo, devido às dimensões ou aos efeitos da ação considerada, ser mais bem alcançados ao nível da União.

No que concerne ao Sistema de Alerta Precoce, podemos resumi-lo da seguinte forma: Todos os projetos de atos legislativos devem incluir uma ficha com elementos circunstanciados que permitam apreciar a observância dos princípios da subsidiariedade e da proporcionalidade. As razões que permitam concluir que determinado objetivo da União pode ser melhor alcançado ao nível desta devem ser corroboradas por indicadores qualitativos e, sempre que possível, quantitativos (artigo $5^{\circ}$, Protocolo $\mathrm{n}^{\circ} 2$ ). Esses projetos, devidamente justificados, consoante artigo $4^{\circ}$ do Protocolo $n^{\circ} 2$, serão transmitidos pela instituição proponente, que normalmente é a Comissão, não apenas para as instituições europeias, mas também diretamente para os parlamentos nacionais. Qualquer parlamento nacional ou qualquer das câmaras de um desses parlamentos pode, no prazo de oito semanas a contar da data de envio de um projeto de ato legislativo, dirigir aos presidentes do Parlamento Europeu, do Conselho e da Comissão um parecer fundamentado em que exponha as razões pelas quais considera que o projeto em 
questão não obedece ao princípio da subsidiariedade, isto é, que seria mais apropriado adotar a ação considerada no nível nacional ao invés de adotá-la no nível da União Europeia. Cabe a cada um dos parlamentos nacionais ou a cada uma das câmaras de um Parlamento nacional consultar, nos casos pertinentes, os parlamentos regionais com competências legislativas (artigo $6^{\circ}$, Protocolo $\mathrm{n}^{\circ} 2$ ). Cada parlamento nacional unicameral dispõe de dois votos, sendo que nos sistemas bicamerais cada câmara dispõe de um voto (art. $7^{\circ}, \S 1$, Protocolo $n^{\circ} 2$ ). No caso de os pareceres fundamentados sobre a inobservância do princípio da subsidiariedade num projeto de ato legislativo representarem, pelo menos, um terço do total dos votos atribuídos aos parlamentos nacionais. Depois dessa reanálise, o órgão do qual emanar o projeto de ato legislativo, pode decidir mantê-lo, alterá-lo ou retirá-lo. Essa decisão deve ser fundamentada (art. $7^{\circ}, \S 2$, Protocolo $n^{\circ} 2$ ). 0 protocolo não fixa qualquer prazo para o reexame de um projeto, o que pode ser facilmente explicado, pois a modificação de uma proposição requer obviamente mais tempo do que a sua manutenção ou retirada. Esse procedimento descrito é chamado de procedimento do cartão amarelo. No quadro do processo legislativo ordinário - votação por maioria qualificada e codecisão -, caso os pareceres fundamentados sobre a inobservância do princípio da subsidiariedade numa proposta de ato legislativo representem a maioria simples dos votos atribuídos aos parlamentos nacionais, a proposta deve ser reanalisada. Depois dessa reanálise, a Comissão pode decidir manter a proposta, alterá-la ou retirá-la (art. $7^{\circ}$, 3 , Protocolo $\mathrm{n}^{\circ} 2$ ). No entanto, se a Comissão decidir manter a proposta, caberá ao Conselho e ao Parlamento Europeu decidirem, antes de concluírem a primeira leitura do projeto, com base nas razões apontadas pelos parlamentos nacionais e pela Comissão, se a proposta legislativa é compatível com o princípio da subsidiariedade. Se o legislador considerar que a proposta não é compatível com o princípio da subsidiariedade, ela não continuará a ser analisada (art. $7^{\circ}$, § 3 , Protocolo $\mathrm{n}^{\circ} 2$ ). Esse procedimento, por sua vez, é chamado procedimento do cartão laranja. Destacamos que ele é aplicável apenas ao procedimento legislativo ordinário, enquanto o procedimento do cartão amarelo aplica-se a qualquer proposta de ato legislativo.

A partir da leitura dos dispositivos que instituem esse Sistema emergem algumas questões a serem examinadas. A expressão “propostas de ato legislativo" engloba quais documentos no âmbito da União Europeia? Como essas propostas serão transmitidas aos Parlamentos nacionais? Os números mínimos de votos necessários para deflagrar os procedimentos do cartão amarelo e do cartão laranja foram fixados em um patamar adequado? 0 prazo de oito semanas de que os parlamentos nacionais dispõem para emitir parecer fundamentado acerca da observância da subsidiariedade é muito exíguo, considerando o elevado 
número de propostas legislativas produzidas na União Europeia e a necessidade de coordenação entre os parlamentos nacionais? Em caso de resposta afirmativa, quais as soluções possíveis para amenizar ou solucionar este problema? Podem os parlamentos emitir novo parecer fundamentado, seguindo os parâmetros do Sistema de Alerta Precoce, caso alguma emenda altere substancialmente determinada proposta de ato legislativo, introduzindo determinada disposição que se mostre contrária à subsidiariedade? Além dessas questões, devemos analisar, ainda, outras, como, por exemplo, a razão pela qual não foi incluído um procedimento do cartão vermelho, visto que muitos propunham a adoção de um procedimento pelo qual os parlamentos nacionais pudessem simplesmente impedir que determinada medida fosse adotada pela União Europeia.

O Sistema de Alerta Precoce foi desenvolvido para solucionar dois problemas distintos: Como desenvolver um mecanismo de controle da subsidiariedade sem que fosse necessário criar uma nova instituição; como envolver os parlamentos nacionais na vida democrática da União Europeia. Desta forma, o SAP tem dois objetivos: garantir que a legislação da União Europeia cumpra com a subsidiariedade e reduzir o déficit democrático existente na União Europeia. 0 Tratado de Lisboa amplia as oportunidades para que os parlamentos nacionais exerçam influência política no sentido de garantir a aplicação do princípio da subsidiariedade. Com a consagração do Sistema de Alerta Precoce, a ligação entre a Comissão e os parlamentos tornouse mais forte, tendo em vista o reconhecimento do direito de estes receberem diretamente os documentos daquela. Anteriormente à criação desse sistema, discutiu-se a respeito da introdução de uma "terceira câmara" na União Europeia, constituída por parlamentares nacionais. Sugeriram-se, ainda, outras opções, como a criação de câmaras do Tribunal de Justiça, ou mesmo a criação de um novo tribunal, encarregadas de garantir a observância da subsidiariedade. Outras sugestões incluíam a criação de um comitê especial de parlamentares nacionais ou a designação de um membro específico da Comissão para assegurar o respeito da subsidiariedade. Como podemos avaliar o SAP em relação a esses outros mecanismos? Não seria melhor reforçar o controle jurídico exercido pelo Tribunal de Justiça, ao invés de atribuir essa tarefa de controle aos Parlamentos Nacionais?

Neste trabalho, estudamos especificamente o Sistema de Alerta Precoce, destacando os seus objetivos, as suas principais características e buscando encontrar soluções para os problemas que emergem a partir do exame do Protocolo relativo à aplicação dos princípios da subsidiariedade e da proporcionalidade. Em suma, o objetivo deste trabalho é traçar as linhas definidoras do Sistema de Alerta Precoce e avaliar se ele é um instrumento adequado para 


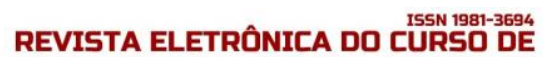

controlar a aplicação do princípio da subsidiariedade e, consequentemente, assegurar que as decisões sejam tomadas tão próximo quanto possível dos cidadãos da União Europeia.

\section{PROTOCOLO Nº 2 DO TRATADO DA UNIÃO EUROPEIA}

O Tratado da União Europeia, alterado pelo Tratado de Lisboa, traz consigo um Protocolo relativo à aplicação dos princípios da subsidiariedade e da proporcionalidade Protocolo $\mathrm{n}^{\circ} 2$, no qual estão contidas as principais disposições acerca do Sistema de Alerta Precoce. A seguir, examinaremos esses dispositivos e as principais questões relacionadas a esse sistema.

\subsection{Considerações Gerais}

O Protocolo relativo à aplicação dos princípios da subsidiariedade e da proporcionalidade determina que cabe a cada instituição assegurar "continuamente a observância dos princípios da subsidiariedade e da proporcionalidade definidos no artigo $5^{\circ}$ do Tratado da União Europeia". Portanto, todas as instituições comunitárias são responsáveis por controlar a aplicação da subsidiariedade dentro de suas respectivas áreas de competência. No que se refere aos parlamentos nacionais, a primeira verificação é feita ainda na etapa de programação legislativa, quando todos os documentos do programa legislativo anual da Comissão são submetidos a uma avaliação preliminar (art. $1^{\circ}$, Protocolo n. 1). Um controle mais substancial é, então, feito em relação às propostas de ato legislativo", as quais "devem incluir uma ficha com elementos circunstanciados que permitam apreciar a observância dos princípios da subsidiariedade e da proporcionalidade" (art. $5^{\circ}$ do Protocolo n. $2^{2}$ ). Desta forma, para que o princípio seja efetivamente aplicado, é necessário que haja um diálogo institucional, principalmente entre o Parlamento Europeu, o Conselho e a Comissão ${ }^{3}$, visto que estas são as principais instituições no que tange à elaboração dos atos legislativos da União.

O Protocolo n. 2 do TUE estabelece o controle sobre a aplicação da subsidiariedade como um controle essencialmente procedimental, no qual as instituições legislativas são dirigidas a averiguarem, antes de adotarem qualquer ação, se esta deve realmente ser adotada pela União

\footnotetext{
${ }^{1}$ CÂMARA DOS LORDES, 2005, p. 36.

2 UNIÃO EUROPEIA, 2010 a.

${ }^{3}$ CAMPOS, João Mota de. Direito Comunitário. v. 1, 8. ed. Lisboa: Fundação Calouste Gulbenkian, 1997. p. 633.
} 
Europeia ao invés de ser adotada pelos Estados-membros ${ }^{4}$. Conforme ensina George Bermann, "subsidiariedade essencialmente descreve um método de análise política que cada participante do processo legislativo comunitário deveria seguir ao decidir propor, apoiar ou aprovar uma dada medida" 5 . Tendo por base as decisões proferidas pelo Tribunal de Justiça da União Europeia, as quais tem priorizado garantir a integração ao invés de reforçar a subsidiariedade ${ }^{6}$, o procedimento de controle da subsidiariedade pelos parlamentos nacionais é de maneira geral apoiado pela doutrina, embora as limitações desse sistema sejam reconhecidas.

Há autores, contudo, que entendem que as medidas adotadas para garantir a aplicação da subsidiariedade são inadequadas, pois elas atribuem a decisão acerca da violação do princípio à Comissão, ao Conselho, ao Parlamento Europeu e ao Tribunal de Justiça da União Europeia, órgãos que estariam interessados em aumentar os seus poderes por meio da ampliação das competências comunitárias ${ }^{7}$. Uma considerável inovação introduzida pelo Tratado de Lisboa, em comparação com a proposta de Tratado Constitucional, consiste na introdução do procedimento do cartão laranja. Contudo, mesmo nesse procedimento, os parlamentos não terão a possibilidade de bloquear a adoção de uma proposta e, tampouco, será alterada a maioria qualificada exigida para a aprovação da medida. Desta forma, segundo alguns autores, o processo legislativo da União Europeia continua funcionando conforme a mesma lógica institucional ${ }^{8}$.

Questão que precisa ser esclarecida é o que aconteceria se esse procedimento fosse deflagrado e a Comissão alterasse a sua proposta, mas mantivesse alguma das partes problemáticas no que se concerne à observância da subsidiariedade. Quando se discutia a inclusão do Protocolo relativo à subsidiariedade no Tratado Constitucional, foi proposta a inclusão de uma segunda fase no Sistema de Alerta Precoce. Contudo, essa proposta foi rejeitada, pois os membros da Convenção temiam que o sistema legislativo se tornasse mais complexo e ineficiente 9 . Tendo isso em vista e adotando uma interpretação literal do artigo $7^{\circ}$ (3) do Protocolo $n^{\circ} 2$, somos levados a crer que a hipótese de segunda fase do procedimento do

\footnotetext{
${ }^{4}$ BERMANN, George A. Taking Subsidiarity Seriously: Federalism in the European Community and the United States. Columbia Law Review, Nova lorque , v. 94, n. 2, p. 331-456, 1994. p. 336.

${ }^{5}$ BERMANN, 1994, p. 382.

${ }^{6}$ ESTELLA, Antonio. The EU Principle of Subsidiarity and Its Critique. Nova lorque: Oxford University Press, 2002.

${ }^{7}$ BERNHOLZ, Peter. How to Safeguard Subsidiarity and Competition in the European Union. RMM-Journal, Frankfurt, v. 0, p. 327-334, 2009. p. 331.

8 KIIVER, Philipp. The Treaty of Lisbon, the National Parliaments and the Principle of Subsidiarity. Maastricht Journal of European and Comparative Law, Maastricht, v. 15, p. 77-83, 2008. p. 77 e 78.

${ }^{9}$ COOPER, 2008, p. 7-9.
} 


\title{
政

cartão laranja - ponderação dos pareceres fundamentados pelo legislador da União - não seria compatível com os $\operatorname{Tratados}^{10}$.

\subsubsection{Transmissão das propostas aos parlamentos nacionais}

No que diz respeito à transmissão das propostas de atos legislativos aos parlamentos nacionais, cabe citar o artigo $4^{\circ}$ do Protocolo $n^{\circ} 2$, que dispõe:

\begin{abstract}
A Comissão envia os seus projetos de atos legislativos e os seus projetos alterados aos Parlamentos nacionais, ao mesmo tempo que ao legislador da União. 0 Parlamento Europeu envia os seus projetos de atos legislativos e os seus projetos alterados aos Parlamentos nacionais. O Conselho envia aos Parlamentos nacionais os projetos de atos legislativos emanados de um grupo de Estados-membros, do Tribunal de Justiça, do Banco Central Europeu ou do Banco Europeu de Investimento, bem como os projetos alterados.

Logo que sejam adotadas, as resoluções legislativas do Parlamento Europeu e as posições do Conselho serão enviadas por estas instituições aos Parlamentos nacionais.
\end{abstract}

0 artigo $3^{\circ}$ do referido Protocolo, por sua vez, esclarece o significado da expressão "projeto de ato legislativo", a qual engloba, além das propostas da Comissão, "as iniciativas de um grupo de Estados-membros, as iniciativas do Parlamento Europeu, os pedidos do Tribunal de Justiça, as recomendações do Banco Central Europeu e os pedidos do Banco Europeu de Investimento, que tenham em vista a adoção de um ato legislativo". 0 artigo $2^{\circ}$ do Protocolo $n^{\circ}$ 1, relativo ao papel dos parlamentos nacionais na União Europeia, basicamente reproduz o conteúdo desses dois dispositivos citados acima, ressaltando que os projetos de atos legislativos “dirigidos ao Parlamento Europeu e ao Conselho são enviados aos Parlamentos nacionais". De acordo com o artigo $1^{\circ}$ do Protocolo $\mathrm{n}^{\circ} 1$ a Comissão tem também o dever de enviar "aos parlamentos nacionais os seus documentos de consulta (livros verdes, livros brancos e comunicações), o programa legislativo anual e qualquer outro instrumento de programação legislativa ou de estratégia política". Essas disposições inovam em relação àquelas constantes no Tratado de Amsterdã. O Protocolo relativo ao papel dos parlamentos nacionais na União Europeia deste Tratado determinava apenas o envio dos documentos de consulta da Comissão diretamente aos parlamentos nacionais dos estados membros, enquanto que as propostas legislativas da Comissão deviam ser transmitidas aos governos de cada Estado-membro, cabendo a estes assegurar que os respectivos parlamentos recebessem a tempo as propostas. Portanto, agora a transmissão ocorre diretamente aos parlamentos nacionais, sem passar por qualquer

\footnotetext{
${ }^{10}$ ROTHENBERGER; VOGT, 2007, p. 14
} 
filtragem pelos governos, garantindo assim um maior tempo para aqueles analisarem as propostas $^{11}$. Pela primeira vez é estabelecida uma ligação direta entre cada parlamento e as instituições da União Europeia ${ }^{12}$. Contudo, antes mesmo do Tratado de Lisboa, a Comissão, então presidida por José Manuel Barroso, anunciou, em 2006, que transmitiria todas as novas propostas e consultas diretamente aos parlamentos nacionais, convidando-os a interagir na atuação dos órgãos da União Europeia ${ }^{13}$.

\subsubsection{Limiares de votação}

Conforme dito anteriormente, a deflagração do procedimento do cartão amarelo exige pelo menos um terço do total de votos atribuídos aos parlamentos nacionais, lembrando que os parlamentos unicamerais dispõem de dois votos e que nos parlamentos bicamerais cada câmara dispõe de um voto. Tendo em vista que a União Europeia é composta por 27 Estados-membros, são atribuídos aos parlamentos nacionais 54 votos. Logo a deflagração desse procedimento exige pelo menos 18 votos. Este limiar é reduzido a um quarto - 14 votos - "quando se tratar de um projeto de ato legislativo apresentado com base no artigo $76 .^{\circ}$ do Tratado sobre 0 Funcionamento da União Europeia”. Este artigo se refere a matérias relativas ao espaço de liberdade, segurança e justiça, incluindo cooperação judiciária em matéria penal e cooperação policial.

Cabe ressaltar que o Conselho opera em uma cultura de consenso. É muito difícil que qualquer legislação seja aprovada com a oposição de mais de três Estados-membros. Além disso, tendo em vista a predominância do sistema parlamentar nos Estados integrantes da União Europeia, não se pode enxergar os parlamentos nacionais e os governos como instituições completamente separadas. De um modo geral, o governo e a maioria do parlamento estão diretamente vinculados: o governo depende da confiança da maioria para manter-se e, enquanto dispõe dessa confiança, tem controle sobre ela. No entanto, nos governos de coalizão este controle do governo sobre o parlamento pode não ser tão efetivo. De qualquer modo, isso nos leva a concluir que o limiar de votos exigido para o procedimento do cartão amarelo é muito alto. Seria praticamente impossível para o Conselho aprovar qualquer ato legislativo que

${ }^{11}$ CÂMARA DO LORDES, 2005, p. 29

${ }^{12}$ ASSEMBLEIA NACIONAL, 2004, p. 17-18.

13 BOURDIN, Delphine; VARA ARRIBAS, Gracia. The Role of Regional Parliaments in the Process of Subsidiarity Analysis within the Early Warning System of the Lisbon Treaty. Bruxelas: Comité das Regiões, 2010. RAUNIO, Tapio. Destined for irrelevance? Subsidiarity control by National Parliaments. Madri: Elcano Royal Institute, 2010. 


\section{D.

contasse com a oposição de um terço ou mesmo de um quarto dos parlamentos nacionais ${ }^{14}$. Mas mesmo que esses limiares não sejam atingidos, é provável que a Comissão, por questões políticas, reconsidere a sua posição, principalmente nos casos em que alguns dos maiores Estados-membros forem contra, ou mesmo caso algum Estado-membro manifeste-se ferrenhamente contrário ao projeto legislativo ${ }^{15}$. Além disso, se o limiar de um terço for atingido, mesmo que a Comissão persista com a proposta sem alterá-la, será extremamente difícil reunir a maioria qualificada dos votos no Conselho, pois os ministros dos Estados-membros cujos parlamentos tenham emitido parecer contrário à proposta correriam um considerável risco político ao votarem em favor desta ${ }^{16}$.

O Tratado de Lisboa inovou em relação à proposta de Tratado Constitucional ao consagrar o procedimento do cartão laranja, aplicável ao processo legislativo ordinário (codecisão). De acordo com o artigo $7^{\circ}(3)$ do Protocolo $\mathrm{n}^{\circ} 2$, este procedimento é deflagrado pela "maioria simples dos votos atribuídos aos Parlamentos nacionais". Contudo, entende-se que essa maioria deve ser calculada sobre o total de votos atribuídos aos parlamentos, não sobre o total de votos lançados, isto é, trata-se de maioria absoluta, não de maioria simples ${ }^{17}$, de outra forma, bastaria que um único parlamento, se os outros não se manifestassem, emitisse um parecer fundamentado sobre a inobservância do princípio da subsidiariedade numa proposta de ato legislativo para dar início a esse procedimento. Portanto, são necessários 28 dos 54 votos atribuídos aos parlamentos. Por meio do mecanismo do "cartão laranja", se a Comissão optar por manter a proposta questionada pelos parlamentos, a justificativa para a manutenção dessa proposta, juntamente com as opiniões manifestadas pelos parlamentos nacionais, será submetida ao legislador da União. Esse último considerará se a proposta é compatível com o princípio da subsidiariedade. Se uma de suas câmaras, Parlamento ou Conselho, entender que a proposta viola o princípio da subsidiariedade, a proposta é rejeitada antes da primeira leitura.

\footnotetext{
${ }^{14}$ CÂMARA DOS COMUNS, 2008, p. 44-45

15 FLYNN, Brendan. Reformed Subsidiarity in the Constitution for Europe: Can it deliver on expectations? Maastricht: European Institute of Public Administration, 2005. p. 17. Esse entendimento é manifestado também, nos seguintes termos, pela Assembleia Nacional da França: Mais on peut raisonnablement penser que la Commission n'adoptera pas une lecture comptable des dispositions du protocole. Elle sera la plupart du temps politiquement tenue, même si le seuil d'un quart ou d'un tiers des voix n'est pas atteint, de réexaminer un projet d'acte législatif faisant l'objet d'un nombre d'avis motivés émanant de chambres parlementaires représentant un nombre significatif de citoyens de l'Union. En pratique, c'est le seuil de la minorité de blocage au Conseil qui devrait se révéler le véritable critère d'appréciation de la Commission, davantage que le seuil d'un quart ou d'un tiers des voix fixé par le protocole (ASSEMBLEIA NACIONAL, 2004, p. 22 e 23).
}

${ }^{16}$ CÂMARA DOS COMUNS, 2008, p. 38

${ }^{17}$ KIIVER, 2008, p. 81 
No caso do Conselho, a rejeição exige a maioria de 55\% de seus membros; no Parlamento, requer a maioria simples dos votos lançados. Enquanto esse procedimento torna um pouco mais fácil para o Parlamento Europeu rejeitar uma proposta com base na violação da subsidiariedade, ainda é mais difícil para o Conselho bloquear a adoção de uma proposta com base nesse fundamento do que com base simplesmente no mérito da proposta. Por essa razão, a doutrina entende que dificilmente um projeto legislativo será bloqueado com fundamento no artigo $7^{\circ}(3)$ do Protocolo ${ }^{18}$.

\title{
1.1.3 Prazo de oito semanas
}

O artigo $4^{\circ}$ do Protocolo relativo ao papel dos parlamentos nacionais da União Europeia prevê:

\begin{abstract}
Deve mediar um prazo de oito semanas entre a data em que um projeto de ato legislativo é transmitido aos Parlamentos nacionais, nas línguas oficiais da União, e a data em que o projeto é inscrito na ordem do dia provisória do Conselho com vista à sua adoção ou à adoção de uma posição no âmbito de um processo legislativo. São admissíveis exceções em casos de urgência, cujos motivos devem ser especificados no ato ou posição do Conselho. Salvo em casos urgentes devidamente fundamentados, durante essas oito semanas não poderá verificar-se qualquer acordo sobre o projeto de ato legislativo. Salvo em casos urgentes devidamente fundamentados, deve mediar um prazo de dez dias entre a inscrição do projeto de ato legislativo na ordem do dia provisória do Conselho e a adoção de uma posição.
\end{abstract}

Embora o Tratado de Lisboa tenha ampliado em relação à proposta de Tratado Constitucional, o prazo para que os parlamentos nacionais se manifestem a respeito da subsidiariedade, este ainda pode ser insuficiente, considerando: a) a necessidade de consultar órgãos especializados, como, por exemplo, comitês, dentro dos próprios parlamentos, de forma a realizar uma triagem dentre os projetos de atos legislativos para identificar aqueles que apresentem algum interesse no que tange ao controle da subsidiariedade e, sendo o caso, redigir um parecer fundamentado; b) a eventual necessidade de consultar parlamentos regionais; c) a necessidade de trocar informações com outros parlamentos e de saber o resultado da análise feita por esses, tornando, desta forma, possível a coordenação de suas posições, algo que é

${ }^{18}$ SCHÜTZE, Robert. Subsidiarity after Lisbon: reinforcing the safeguards of federalism. Cambridge Law Journal, Cambridge, v. 68 (3), p. 525-536, nov. 2009. KIIVER, 2008, p. 81. 


\section{政

essencial para o êxito do procedimento; d) decidir, finalmente, a respeito da adoção formal do parecer motivado e enviá-lo à instituição europeia competente ${ }^{19}$.

0 grande número de propostas legislativas, que tende a crescer com o aprofundamento do processo de integração, pode acabar sobrecarregando os órgãos dos parlamentos nacionais encarregados dos assuntos relativos à União ${ }^{20}$. Para que o exame dos projetos de atos legislativos funcione bem e, consequentemente, para que o Sistema de Alerta Precoce possa produzir resultados positivos, é necessária a existência de algum procedimento de priorização que possa indicar, no âmbito dos parlamentos nacionais, a existência de determinada proposta que requeira atenção com urgência e, talvez, a emissão de um parecer que exponha possível violação do princípio da subsidiariedade. Essa triagem é essencial, pois há uma grande quantidade de propostas que contemplam apenas questões técnicas, com pouca ou nenhuma repercussão política, mas é preciso analisar todas as propostas para encontrar aquelas que se revestem de uma dimensão política mais destacada ${ }^{21}$. Desta forma, parece apropriada a indicação de um relator em cada parlamento, encarregado de verificar as propostas especificamente quanto à subsidiariedade e de alertar nos casos em que haja alguma dúvida a respeito de sua observância. Cabe destacar a importância de uma atuação rápida a esse respeito, tendo em vista que o tempo para análise de uma proposta e a eventual emissão de parecer é exíguo ${ }^{22}$.

Deve-se considerar ainda que os parlamentos não estarão sempre disponíveis para analisar imediatamente os textos que lhes serão transmitidos, como, por exemplo, nos períodos que não estiverem compreendidos nas sessões parlamentares, já que o calendário legislativo da União não é calculado com base naquele dos Estados-membros ${ }^{23}$. Contudo, o prazo de oito semanas nos parece apropriado, pois uma dilação poderia dificultar excessivamente o andamento do processo legislativo europeu. A solução para enfrentar este prazo diminuto reside em iniciar o processo de verificação ainda na fase pré-legislativa, ou seja, na fase dos documentos de consulta - livros verdes, livros brancos, comunicações - que precede a elaboração formal das propostas de atos legislativos ${ }^{24}$. Os parlamentos nacionais devem, outrossim,

\footnotetext{
${ }^{19}$ BERMANN, George A. The Lisbon Treaty: The Irish 'No'. National Parliaments and Subsidiarity: An Outsider's View. European Constitutional Law Review, Cambridge, v. 4, p. 453-459, 2008. p. 458; ASSEMBLEIA NACIONAL, 2004, p. 27.

${ }^{20}$ FLYNN, 2005, p. 16.

${ }^{21}$ ASSEMBLEIA NACIONAL, 2004, p. 26.

${ }^{22}$ FLYNN, 2005, p. 17

${ }^{23}$ ASSEMBLEIA NACIONAL, 2004, p. 28

${ }^{24}$ BERMANN, 2008, p. 458
} 


\section{(1)

consultar o programa legislativo anual e qualquer outro instrumento de programação legislativa ou de estratégia política da Comissão para conhecerem com antecedência medidas que possam mostrar-se controversas quanto à questão da subsidiariedade ${ }^{25}$. Necessário frisar que a capacidade dos parlamentos nacionais influenciarem o processo legislativo não se esgota após o período de oito semanas. Eles conservam a sua prerrogativa de controle parlamentar sobre o trabalho do Conselho. Nada os impedirá de se manifestarem após o prazo, enquanto o texto não tiver sido aprovado definitivamente. Tratando-se de Estados nos quais os governos tem a origem de seu mandato no parlamento, aperfeiçoar o exame dos assuntos da União Europeia no nível nacional pode ser um meio mais efetivo de influenciar o Conselho e consequentemente a adoção de atos legislativos do que emitir pareceres fundamentados acerca da subsidiariedade ${ }^{26}$.

\subsection{Propostas de emenda}

O protocolo não esclarece se os parlamentos podem emitir novo parecer fundamentado, seguindo os parâmetros do Sistema de Alerta Precoce, caso alguma emenda altere substancialmente determinada proposta de ato legislativo, introduzindo determinada disposição que se mostre contrária à subsidiariedade, isto é, é perfeitamente possível que uma proposta seja analisada pelos parlamentos e estes não encontrem qualquer problema em relação à subsidiariedade, mas, posteriormente, durante o desenrolar do processo legislativo no Parlamento Europeu e no Conselho, sejam incluídas alterações contrárias à subsidiariedade. Nesses casos, o Sistema de Alerta Precoce não poderá mais ser empregado ${ }^{27}$, restando aos parlamentos apenas tentar influenciar os ministros do Conselho representantes de seus respectivos Estados-membros e os membros do Parlamento Europeu. Deve-se considerar que o objetivo desse sistema não é conferir um poder de veto aos Parlamentos nacionais, apenas incentivar a sua participação e, em alguma medida, oportunizar que eles influam no processo legislativo europeu. Conforme referido anteriormente, quando se discutia a inclusão do Protocolo relativo à subsidiariedade no Tratado Constitucional, foi proposta a inclusão de uma segunda fase no Sistema de Alerta Precoce. Contudo, essa proposta foi rejeitada, pois os

${ }^{25}$ CÂMARA DOS LORDES, 2005, p. 31

${ }^{26}$ ROTHENBERGER; VOGT, 2007, p. 15; ASSEMBLEIA NACIONAL, 2004, p. 29.

${ }^{27}$ ASSEMBLEIA NACIONAL, 2004, p. 21 e 22 


\section{(1)

membros da Convenção temiam que o sistema legislativo se tornasse mais complexo e ineficiente ${ }^{28}$.

Há, contudo, quem entenda que a prerrogativa dos parlamentos nacionais de considerar e emitir pareceres sobre as propostas não esta limitada às propostas originais, incluindo também as propostas emendadas. Essa interpretação tem supedâneo no artigo $4^{\circ}$ do Protocolo relativo à aplicação do princípio da subsidiariedade, o qual determina que não somente os projetos de atos legislativos são enviados aos parlamentos nacionais, mas também "os seus projetos alterados". Nesse sentido, seria defensável arguir que a expressão “os seus projetos alterados” (amended drafts) fosse interpretada de forma ampla, de modo a incluir todos os casos em que uma proposta é alterada substancialmente durante as negociações no Conselho e no Parlamento Europeu $^{29}$.

Não há, de acordo com a nossa opinião, nada que impeça os Parlamentos nacionais de emitirem pareceres referentes a eventuais emendas nos projetos legislativos. No entanto, não nos parece que as instituições europeias devam aguardar o prazo de oito semanas, previsto para os projetos, ou que elas devam obrigatoriamente reanalisar a emenda se os pareceres atingirem o número mínimo de votos exigido pelo Sistema de Alerta Precoce. Devemos considerar a preocupação, expressa pela Convenção Europeia quando traçou as linhas básicas desse sistema, em velar para que ele não delongue o processo legislativo, não o bloqueie nem dê origem a uma nova burocracia.

\subsection{Procedimento do cartão vermelho}

Não foi aprovada a inclusão do procedimento do cartão vermelho no Tratado da União Europeia, ou seja, de um procedimento pelo qual os parlamentos nacionais pudessem simplesmente impedir que determinada medida fosse adotada. A razão para essa limitação é que o Sistema de Alerta Precoce não tem por objetivo tornar os parlamentos nacionais “colegisladores" na União Europeia ${ }^{30}$. O Sistema de Alerta Precoce coloca-se como um complemento ao principal papel dos parlamentos nacionais no âmbito europeu, o qual consiste em monitorar a atuação de seus respectivos governos. Por essa razão, o escopo do Sistema de Alerta Precoce é restrito à observância do princípio da subsidiariedade, pois os parlamentos

\footnotetext{
${ }^{28}$ COOPER, 2008, p. 7-9

${ }^{29}$ CÂMARA DOS LORDES, 2005, p. 30 e 31.

${ }^{30}$ COOPER, lan. The Watchdogs of Subsidiarity: National Parliaments and the Logic of Arguing in the EU. JCMS: Journal of Common Market Studies, London, v. 44, n. 2, 2006, p. 281-304. p. 290.
} 


\section{政

podem expressar as suas opiniões a respeito do mérito das propostas diretamente aos seus próprios governos $^{31}$. Outro motivo para a não adoção de um procedimento de cartão vermelho é que ele seria incompatível com a independência da Comissão, assegurada pelo Tratado da União Europeia, e distorceria o complexo sistema de distribuição de poder e de responsabilidade na União Europeia ${ }^{32}$. Atribuir aos parlamentos nacionais a possibilidade de vetar propostas da Comissão interferiria com o direito exclusivo de iniciativa deste órgão, além de interferir também com o papel dos membros do Conselho como representantes dos governos nacionais no processo decisório da União Europeia ${ }^{33}$. Estar-se-ia, além disso, atribuindo poderes aos parlamentos nacionais sem que fosse atribuída uma responsabilidade correspectiva. Caso eles pudessem simplesmente vetar as propostas da Comissão, eles teriam menos incentivo a ingressar em um diálogo construtivo com esta a respeito de como uma determinada proposta poderia ser melhorada e, desta forma, adequar-se ao princípio da subsidiariedade ${ }^{34}$.

Contudo, alguns ainda entendem que o procedimento do cartão vermelho deveria ter sido implementado ${ }^{35}$. A Câmara dos Comuns do Reino Unido, por exemplo, manifesta-se no sentido de que para que os parlamentos envolvam-se de maneira substancial nos trabalhos da União Europeia é indispensável um sistema de "cartão vermelho" que obrigue a Comissão a retirar propostas que ameacem violar o princípio da subsidiariedade ${ }^{36}$.

\subsection{Controle da proporcionalidade}

Embora o Protocolo relativo à aplicação do princípio da subsidiariedade e da proporcionalidade faça referência expressa a ambos os princípios e a Comissão seja obrigada a fundamentar os seus projetos de atos legislativos também em relação a ambos, os parlamentos nacionais somente podem emitir pareceres fundamentados a respeito do princípio da subsidiariedade $^{37}$. Isso implica em um grande estreitamento do escopo desse sistema de controle, pois, por força do artigo $5^{\circ}$ (3) do Tratado da União Europeia, só cabe analisar a observância da subsidiariedade em se tratando de competências não exclusivas da União

\footnotetext{
${ }^{31}$ COOPER, 2008, p. 9 e 10.

${ }^{32}$ SCHÜTZE, 2009, p. 530 e 531.

${ }^{33}$ COOPER, 2008, p. 9-10.

${ }^{34}$ COOPER, 2006, p. 290.

${ }^{35}$ BERMANN, 2008, p. 454.

${ }^{36}$ CÂMARA DOS COMUNS, 2008, p. 10 e 11.

${ }^{37}$ ROTHENBERGER; VOGT, 2007, p. 3.
} 
Europeia $^{38}$. Esta ausência, segundo lan Cooper, é absurda e contraprodutiva. Se esta regra for estritamente seguida, haverá efeitos negativos na qualidade da deliberação decorrente da troca de opiniões entre os parlamentos e a Comissão. Para que ocorra um diálogo construtivo entre os parlamentos nacionais e a Comissão, é indispensável que o escopo do Sistema de Alerta Precoce seja ampliado de modo a incorporar o exame da proporcionalidade ${ }^{39}$.

O controle da subsidiariedade, tal como disposto no Tratado, envolve deliberação em torno dos fins: é apropriado que a União Europeia atue em determinado caso? Já o controle da proporcionalidade envolve deliberação a respeito dos meios: determinada ação é a que causa menos restrição a outros direitos dentre aquelas apropriadas para solucionar o problema enfrentado? No entanto, essas duas questões são profundamente imbricadas. Decidir se a União deve agir, implica saber a forma pela qual ela agirá. Se uma pessoa, por exemplo, tem uma infecção em um dedo, ela enfrenta duas questões distintas: a) ela deve se submeter a um tratamento médico? b) como esse tratamento será realizado? Essa pessoa vai a um médico que propõe duas alternativas de tratamento. Uma delas consiste em ingerir um comprimido de antibiótico, a outra consiste em amputar o braço. A pergunta que colocamos é a seguinte: a resposta à questão "b" não terá influência sobre a resposta à questão "a"? De modo semelhante, saber como a União agirá influencia a decisão dos Estados-membros a respeito de se opor ou não a essa ação. Em outras palavras, se a União Europeia for agir em determinado domínio de forma a restringir injustificadamente a autonomia dos Estados-membros, talvez a melhor decisão seja que simplesmente ela não aja de forma alguma e o exercício naquele domínio continue a cargo dos Estados-membros.

O fato de que os parlamentos nacionais não possuem um entendimento comum sobre os princípios da subsidiariedade e da proporcionalidade restou comprovado quando a COSAC Conference of Parliamentary Committees for Union Affairs of Parliaments of the European Union - fez uma simulação do funcionamento do Sistema de Alerta Precoce antes da entrada em vigor do Tratado de Lisboa. Podemos apontar como exemplo a comparação entre as opiniões emitidas pelo Senado francês e pelo Bundesrat alemão. Embora ambos parlamentos tenham considerado que a proposta de diretiva sobre segurança nas rodovias violava a subsidiariedade, eles chegaram a esta conclusão por fundamentos diversos. O Bundesrat indicou que a medida proposta na diretiva tinha sido implementada na Alemanha na forma de programas de segurança e que a ação no nível da União Europeia era, portanto, desnecessária. O Senado francês

\footnotetext{
${ }^{38}$ RAUNIO, 2010, p. 6.

${ }^{39}$ COOPER, 2008, p. 20 e 21.
} 


\section{(1)

destacou que um intercâmbio das melhores práticas entre os Estados-membros seria suficiente para garantir a segurança nas rodovias, tornando supérflua a atuação direta no nível europeu. A opinião do Senado francês poderia ser considerada como um argumento referente à proporcionalidade $^{40}$. Apesar de os princípios da subsidiariedade e da proporcionalidade serem diferentes, eles são fortemente interligados. Na prática, pode ser difícil separar os dois conceitos ou encontrar uma clara demarcação entre eles. Quando pensamos na intensidade apropriada de uma atuação da União Europeia, não estamos tratando apenas do princípio da proporcionalidade, mas também do princípio da subsidiariedade ${ }^{41}$.

\section{OBJETIVOS DO SISTEMA DE ALERTA PRECOCE}

O Sistema de Alerta Precoce foi desenvolvido para solucionar dois problemas distintos: Como desenvolver um mecanismo de controle da subsidiariedade sem que fosse necessário criar uma instituição; como envolver os parlamentos nacionais na vida democrática da União Europeia. Desta forma, o SAP tem dois objetivos: garantir que a legislação da União Europeia cumpra com a subsidiariedade e reduzir o déficit democrático existente na União Europeia. 0 resultado final é um mecanismo de controle da subsidiariedade eminentemente político, limitado quanto ao seu escopo e quanto ao seu poder.

\subsection{Observância do princípio da subsidiariedade}

O Tratado de Lisboa amplia as oportunidades para que os parlamentos nacionais exerçam influência política no sentido de garantir a aplicação do princípio da subsidiariedade ${ }^{42}$. Contudo, alguns consideram o Sistema de Alerta Precoce insignificante. O Parlamento Finlandês, por exemplo, considera esse sistema um processo político ilusório pelas seguintes razões: a) 0 Tratado de Lisboa não cria nenhuma nova tarefa para os parlamentos, considerando-se que estes sempre tiveram acesso às informações referentes ao processo legislativo europeu e a possibilidade de manifestar as suas opiniões aos seus governos ou às instituições europeias. b) Embora a subsidiariedade seja importante enquanto princípio, em termos políticos ela é menos importante do que o conteúdo das propostas, mas o Tratado não atribui aos parlamentos

\footnotetext{
${ }^{40}$ ROTHENBERGER; VOGT, 2007, p. 10.

${ }^{41}$ CÂMARA DOS LORDES, 2005, p. 20.

${ }^{42}$ BERMANN, 2008, p. 453.
} 


\section{政

qualquer possibilidade de expressão a esse respeito. c) A concepção de subsidiariedade consagrada é tão estreita que torna o conceito praticamente insignificante ${ }^{43}$.

A Câmara dos Comuns, de modo semelhante, duvida que o Sistema de Alerta Precoce produza grandes efeitos práticos em relação à influência que aquele parlamento exerce no processo legislativo europeu, considerando especialmente o fato de que examinar as propostas da União Europeia quanto à observância do princípio da subsidiariedade tem sido a prática adotada no Reino Unido desde que o princípio foi introduzido, em 1993, através do Tratado de Maastricht. Segundo a posição da Câmara dos Comuns, a Comissão e os Estados-membros já se ocupavam com o exame da subsidiariedade e já consideravam as opiniões dos parlamentos nacionais $^{44}$. Tapio Raunio, por sua vez, considera que o sistema foi criado em decorrência da preocupação com a legitimidade das instituições da União Europeia e terá apenas um impacto marginal ${ }^{45}$, predominantemente simbólico ${ }^{46}$.

Consideramos que nem todos os parlamentos nacionais possuem a mesma preocupação em fiscalizar a atuação das instituições europeias demonstrada pela Câmara dos Comuns. Deste modo, o Sistema de Alerta Precoce servirá como incentivo para que todos os Estados-membros se ocupem seriamente com o exame das propostas da União Europeia. Além disso, o fato de ter-se desenvolvido informalmente um diálogo entre a Comissão e os parlamentos ${ }^{47}$ não retira o mérito de uma medida que institucionaliza essa prática e a incentiva. É verdade que a Comissão, o Conselho e o Parlamento Europeu continuam sendo os principais atores quanto à decisão pela adoção de uma proposta. Isso significa que o poder de decisão continua nas mãos das instituições da União Europeia e dos governos nacionais ${ }^{48}$. 0 que os parlamentos nacionais podem fazer, em suma, é solicitar que o órgão proponente reconsidere a sua posição ou justifique melhor a observância do princípio da subsidiariedade ${ }^{49}$. Nesse sentido, cabe distinguir, de um lado, a atribuição de poderes aos parlamentos nacionais, de outro, o estímulo à utilização dos poderes que os parlamentos já dispõem ${ }^{50}$. 0 direito de os parlamentos enviarem pareceres ao órgão propositor de um ato legislativo, com a finalidade de promover a alteração da proposta, não é

\footnotetext{
43 BOURDIN; VARA ARRIBAS, 2010, p. 143

${ }^{44}$ CÂMARA DOS COMUNS, 2008; BOURDIN; VARA ARRIBAS, 2010, p. 143.

${ }^{45}$ RAUNIO, 2010, p. 2.

${ }^{46}$ KIIVER, 2008, p.77-78.

${ }^{47}$ ROTHENBERGER, VOGT, 2007, p. 15.

${ }^{48}$ KIIVER, 2008, p.77-78

49 BOURDIN; VARA ARRIBAS, 2010, p. 145.

${ }^{50}$ KIIVER, 2008, p.77-78.
} 


\section{政

novo em sua essência ${ }^{51}$, mas o Sistema de Alerta Precoce fornece um estímulo para que esse direito seja bem empregado.

É muito difícil que um número suficiente de parlamentos nacionais concorde que determinada medida viola o princípio da subsidiariedade. Mas, ainda que o número necessário para acionar o procedimento do cartão amarelo seja alcançado, a Comissão poderá simplesmente manter a sua posição, mediante justificativa. Contudo, é provável que em tal circunstância a Comissão revise ao menos parcialmente a sua proposta, de outro modo ela acabaria sendo acusada de não ouvir os parlamentos nacionais, representantes do povo ${ }^{52}$, o que poderia gerar uma pressão política muito forte sobre a Comissão - ou seja, qual for o órgão proponente -, causando um impacto no processo de integração. Portanto, mesmo que o limiar de um terço não seja alcançado, quanto maior for o número de objeções oriundas dos parlamentos, maior será a pressão política para que a proposta seja revisada ${ }^{53}$. A simples existência do Sistema de Alerta Precoce deverá fazer com que a Comissão e as outras instituições da União considerem de forma mais intensa o princípio da subsidiariedade, evitando que os procedimentos do cartão amarelo e do cartão laranja sejam deflagrados ${ }^{54}$. Conforme explica o professor Alan Dashwood, Universidade de Cambridge, a aplicação do Sistema de Alerta Precoce poderá eventualmente influenciar a atuação do Tribunal de Justiça da União Europeia, pois este órgão, ao exercer o controle ex post sobre a observância da subsidiariedade, caso o procedimento do cartão amarelo ou do cartão laranja tenha sido deflagrado, disporá de uma documentação mais extensa do que aquela que dispunha antes do Tratado de Lisboa. 0 Tribunal poderá examinar os pareceres fundamentados dos Parlamentos nacionais, a decisão fundamentada do órgão que propôs o ato legislativo - em geral, a Comissão - e, caso o cartão laranja tenha sido utilizado, algum tipo de minuta a respeito do posicionamento do Parlamento Europeu e do Conselho em face dos pareceres fundamentados que tenham a eles sido submetidos. Toda essa documentação ajudará o Tribunal a procedimentalizar a sua apreciação. Ao invés de ter de decidir a questão substancial referente à observância da subsidiariedade pela legislação, poderá o Tribunal analisar se a Comissão e as outras instituições europeias consideraram efetivamente os pareceres motivados que lhes foram transmitidos e se a argumentação utilizada de fato procurou

\footnotetext{
${ }^{51}$ KIIVER, 2008, p.81.

52 RAUNIO, 2010, p. 7.

${ }^{53}$ CÂMARA DOS LORDES, 2005. p. 27.

${ }^{54}$ CÂMARA DOS COMUNS, 2008, p. 35-36.
} 


\section{政

responder às questões suscitadas pelos parlamentos ${ }^{55}$. Isso facilita o trabalho do Tribunal de Justiça, pois, do ponto de vista jurídico, é mais fácil verificar se um procedimento foi seguido corretamente do que se a subsidiariedade foi observada, questão essa predominantemente política.

Em suma, o Sistema de Alerta Precoce pode promover uma maior observância do princípio da subsidiariedade, fazendo com que os atos legislativos da União sejam menos frequentes, melhor focados e respeitem mais a autonomia dos Estados-membros. Mas, isso depende da disposição da Comissão em alterar ou retirar as suas propostas em face dos pareceres dos parlamentos nacionais ${ }^{56}$.

No que tange à troca de informações entre os parlamentos e a Comissão, a partir do Tratado de Lisboa, a ligação entre eles tornou-se mais forte, tendo em vista o reconhecimento do direito de estes receberem diretamente os documentos daquela. De maneira geral, há uma tendência de que a Comissão efetivamente entre em um diálogo com os parlamentos nacionais e, de fato, considere as suas manifestações, incluindo as opiniões expressadas durante a etapa preparatória dos projetos de atos legislativos ${ }^{57}$. Esta cooperação entre esses órgãos contribui para a legitimidade democrática da União e aproxima o processo decisório dos cidadãos europeus $^{58}$. O Sistema de Alerta Precoce deve ser entendido principalmente como um mecanismo destinado a promover a deliberação. Significa dizer que o seu objetivo é promover o diálogo, o debate e a comunicação institucional, algo que é essencial em qualquer ordem democrática. Esse processo deve também servir como um sistema de freios e contrapesos que promova o aprendizado mútuo através da comunicação daqueles que propõem os atos legislativos com os parlamentos nacionais ${ }^{59}$. Deve-se salientar que há um interesse por parte dos parlamentos nacionais em se expressar antes mesmo de receberem os projetos de atos legislativos. Eles têm interesse em preservar as suas atribuições, e é durante o processo de elaboração da proposta pela Comissão que há uma grande chance de influenciá-la por meio da troca de informação com os comissários europeus. A intervenção dos parlamentos é tanto mais eficaz, quanto mais precoce for $^{60}$.

\footnotetext{
${ }^{55}$ CÂMARA DOS LORDES, 2005, p. 37.

${ }^{56}$ COOPER, 2006, p. 283

${ }^{57}$ RAUNIO, 2010, p. 7-9.

${ }^{58}$ CÂMARA DOS LORDES, 2005, p. 7.

${ }^{59}$ FLYNN, 2005, p. 14 e 15.

${ }^{60}$ ASSEMBLEIA NACIONAL, 2004, p. 28
} 


\section{(1)

Ian Cooper, Universidade de Oslo, considera que de certa forma a interação entre a Comissão e os parlamentos nacionais lembra o tradicional sistema de barganha, no qual as instituições políticas defendem os seus respectivos interesses enquanto negociam até atingir um resultado aceitável para todos. Contudo, ele considera que há espaço para uma discussão construtiva, na qual os interlocutores deixam de lado os seus interesses particulares e dedicamse a um diálogo racional a respeito da questão analisada ${ }^{61}$. Caso efetivamente o diálogo estabelecido entre os parlamentos e a Comissão ocorra racionalmente, o Sistema de Alerta Precoce poderá determinar de forma mais clara o conteúdo do princípio da subsidiariedade na União Europeia, tendo em vista que esse Sistema consiste em uma discussão contínua: Apesar de a discussão a respeito de cada projeto de ato legislativo envolver apenas três etapas - proposta da Comissão, resposta dos parlamentos nacionais, contrarresposta da Comissão - esta sequência será repetida indefinidamente. Cada discussão enfocará a observância da subsidiariedade em uma determinada proposta, mas cada uma dessas discussões fará parte de uma contínua discussão a respeito da questão geral referente ao nível apropriado de atuação da UE e do significado da subsidiariedade.

No que se refere à Cooperação interparlamentar, 0 artigo $9^{\circ}$ do Protocolo $\mathrm{n}$. 1 determina que cabe aos parlamentos nacionais e ao Parlamento Europeu definirem em conjunto a organização e a promoção de uma cooperação interparlamentar eficaz e regular ao nível da União. Com relação ao Sistema de Alerta Precoce, não há qualquer regra determinando que os parlamentos devam consultar uns aos outros antes de transmitirem um parecer motivado sobre a violação da subsidiariedade à Comissão - ou a qualquer outro órgão que propuser um projeto de ato legislativo. Contudo, para que esse sistema seja eficaz é preciso que eles ajam coletivamente, por meio da troca de informações, de comparações das melhores práticas e da coordenação de esforços, pois somente assim será possível atingir o limiar de votos exigido ${ }^{62}$. Requer-se cooperação também entre as diferentes câmaras de um mesmo Estado-membro, onde houver parlamentos bicamerais, e isso nem sempre será fácil, pois muitas vezes há diferenças marcantes de composição entre as duas câmaras e o tempo para chegar a um acordo é exíguo ${ }^{63}$.

A necessidade de cooperação restou demonstrada no projeto piloto conduzido pela COSAC a respeito do terceiro pacote ferroviário (third railway package). Nessa oportunidade diversos parlamentos opuseram-se a diferentes propostas do pacote legislativo, mas, apesar da

${ }^{61}$ COOPER, 2006, p. 295.

${ }^{62}$ BERMANN, 2008, p. 455-457.

${ }^{63}$ FLYNN, 2005, p. 18. 


\section{(1)

grande oposição, o limiar de um terço dos votos não foi atingido em relação a nenhuma das propostas $^{64}$. A manifestação de opiniões contraditórias pode, ainda, produzir o efeito contrário ao desejado, ou seja, pode acabar fortalecendo a posição da Comissão no sentido de que não há violação da subsidiariedade ${ }^{65}$.

Cabe mencionar, no que concerne à cooperação interparlamentar, o papel desempenhado pela COSAC, conferência que reúne os comitês dos parlamentos nacionais dos Estados-membros da União Europeia encarregados de tratar dos assuntos europeus e representantes do Parlamento Europeu. Nos encontros bianuais da COSAC, seis membros representam cada parlamento. Estes encontros normalmente ocorrem na capital do país que ocupa a Presidência do Conselho da União Europeia. A COSAC foi formalmente reconhecida pelo Protocolo de Amsterdã. Atualmente, o seu papel é regulado pelo artigo 10 do Protocolo n. 1. Cabe a essa conferência promover o intercâmbio de informações e de melhores práticas entre os Parlamentos nacionais e o Parlamento Europeu e organizar conferências interparlamentares sobre assuntos específicos. A COSAC auxilia, portanto, os parlamentos nacionais a trocarem informações entre si, algo que é muito importante para o funcionamento do Sistema de Alerta Precoce, considerando a necessidade, apontada anteriormente, de os parlamentos coordenarem a sua atuação ao emitirem pareceres motivados em relação à violação do princípio da subsidiariedade ${ }^{66}$. A COSAC pode fazer qualquer contribuição que entender oportuna em relação à preservação deste princípio $^{67}$. Trata-se de um fórum no qual os parlamentares debatem as matérias relacionadas à União Europeia. Esta Conferência dispõe de um secretariado permanente que poderia centralizar o recebimento de pareceres motivados e informar a todos os parlamentos nacionais a respeito de qualquer parecer emitido que atacasse determinado ato com base na violação da subsidiariedade $^{68}$.

Com relação à atribuição da responsabilidade pelo controle da observância da subsidiariedade aos parlamentos nacionais, é necessário frisar que ao longo do período antecedente ao Tratado de Lisboa, discutiu-se a respeito da criação de uma "terceira câmara" na União Europeia, constituída por parlamentares nacionais ${ }^{69}$. Essa câmara teria o poder de bloquear propostas legislativas e deveria velar para que os poderes da União Europeia não

\footnotetext{
64 BERMANN, 2008, p. 459.

${ }^{65}$ ASSEMBLEIA NACIONAL, 2004, p. 29-30.

${ }^{66}$ RAUNIO, 2010, p. 7-9.

${ }^{67}$ ROTHENBERGER; VOGT, 2007, p. 4.

${ }^{68}$ ASSEMBLEIA NACIONAL, 2004, p. 30.

${ }^{69}$ COOPER, 2008, p. 2.
} 


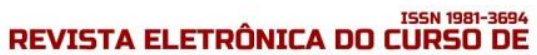

fossem estendidos de modo a violar o princípio da subsidiariedade ${ }^{70}$. Sugeriram-se, ainda, outras opções, como a criação de câmaras do Tribunal de Justiça, ou mesmo a criação de um novo tribunal, encarregadas de garantir a observância da subsidiariedade. Outras sugestões incluíam a criação de um comitê especial de parlamentares nacionais ou a designação de um membro específico da Comissão para assegurar o respeito da subsidiariedade ${ }^{71}$. A vantagem do Sistema de Alerta Precoce é que, ao invés de criar uma instituição com legitimidade duvidosa, ele emprega um conjunto de instituições com legitimidade reconhecida para uma nova finalidade. A ideia de criar uma terceira câmara foi rejeitada, porque complicaria demais a estrutura política da União Europeia. Mas, na verdade, o Sistema de Alerta Precoce integra os parlamentos nacionais em algo que poderia ser chamado de "terceira câmara virtual" - nomenclatura adotada por lan Cooper -, embora com poderes predominantemente consultivos e atuação limitada a um âmbito bastante restrito. Apesar de seus membros não se reunirem em um determinado espaço físico, estão presentes duas das principais funções parlamentares: deliberação e decisão coletiva. Ressalte-se, a deliberação é restrita à observância da subsidiariedade pelas instituições europeias, logo o seu escopo é muito reduzido. O poder de decisão coletiva, por sua vez, é bastante limitado, sendo predominantemente consultivo, salvo no procedimento do cartão laranja, pelo qual uma proposta pode ser bloqueada se houver o apoio de uma das câmaras da União Europeia - Parlamento Europeu ou Conselho ${ }^{72}$.

Quanto ao caráter desse controle envolvido no Sistema de Alerta Precoce, o Grupo de Trabalho sobre o Princípio da Subsidiariedade (Grupo formado por membros da Convenção Europeia que elaborou o projeto de Constituição para a Europa) concluiu que este princípio possui natureza essencialmente política. Deste modo, as instituições europeias devem desfrutar de uma considerável margem de discrição para avaliar se a realização dos objetivos consagrados nos tratados europeus podem ser melhor alcançados atuando-se no nível europeu ou em um nível inferior. Por essa razão, ante a natureza essencialmente política do princípio, deve-se priorizar o controle prévio, antes da entrada em vigor do ato em questão ${ }^{73}$. Nesse sentido, o professor Simon Hix, Faculdade de Economia e Ciência Política de Londres (LSE), aponta a impossibilidade de definir o princípio da subsidiariedade em termos puramente jurídicos ${ }^{74}$. Podemos ilustrar essa afirmação, segundo Hix, com o seguinte exemplo: Se seguíssemos uma definição puramente

\footnotetext{
${ }^{70}$ BERNHOLZ, 2009, p. 333.

${ }^{71}$ BERMANN, 2008, p. 454.

72 COOPER, 2008, p. 6.

${ }^{73}$ CONVENÇÃO EUROPEIA, 2002, p. 3-4

${ }^{74}$ CÂMARA DOS COMUNS, 2008, p. 40.
} 


\section{D.

jurídica da subsidiariedade, diríamos que a política de defesa nacional nos países integrantes da União Europeia, devido à escala e à possibilidade dos bens serem providos ao um menor preço no nível central, deveria ser realizada pela própria União Europeia, contudo isso não ocorre, porque as preferências em matéria de política de defesa são heterogêneas ${ }^{75}$.

George A. Bermann, Universidade de Colúmbia, sustenta que avaliar se uma medida cumpre com a subsidiariedade é um julgamento político, insuscetível a uma avaliação inteiramente objetiva. Segundo ele, teoricamente, as instituições da União Europeia procurariam reduzir ou eliminar as disparidades entre as legislações dos estados membros somente até onde essas disparidades impedissem de forma substancial o livre movimento de um ou mais dos fatores de produção e os ganhos em integração superassem as resultantes perdas de autonomia dos estados membros. Contudo, avaliações desse tipo são profundamente políticas na medida em que elas envolvem julgamentos a respeito de quanto cada ganho incremental em termos de integração econômica representa em termos de custos referentes a outros valores, como diversidade, por exemplo, que consubstanciam a ideia de subsidiariedade ${ }^{76}$.

Em razão do princípio da subsidiariedade ser um princípio profundamente político, tornase inclusive difícil de verificar se determinada instituição, ao adotar certa ação, o observou de fato, tendo em vista que isso depende de uma avaliação dos méritos da medida em questão. Além disso, a aplicação da subsidiariedade implica prever as consequências, em termos de atingimento dos objetivos da União Europeia, de deixar a atuação aos Estados-membros ${ }^{77}$. No entanto, a partir de sua consagração no Tratado de Maastricht, somos obrigados a reconhecer o princípio da subsidiariedade também como um princípio jurídico ${ }^{78}$ do Direito Europeu, ultrapassando concepções que o conceberam apenas como formulação de princípio filosófico ou aspiração de política social ${ }^{79}$. Com efeito, Germán Fernández Farreres, Universidade Complutense de Madri, entende que a indeterminação do princípio da subsidiariedade "não é razão suficiente para negar a substância jurídica de um princípio que, junto a outros,

\footnotetext{
${ }^{75}$ CÂMARA DOS COMUNS, 2008, p.5.

${ }^{76}$ BERMANN, 1994, p. 382.

${ }^{77}$ BERMANN, 1994, p. 335.

${ }^{78}$ BARACHO, José Alfredo de Oliveira. O Princípio de Subsidiariedade: Conceito e Evolução. Rio de Janeiro: Forense, 1997. p. 28.

${ }^{79}$ HORTA, Raul Machado. Federalismo e o Princípio da Subsidiariedade. In: MARTINS, Ives Gandra da Silva (Coord.). As vertentes do direito constitucional contemporâneo. Rio de Janeiro: América jurídica, 2002. p. 461-472. p. 461.
} 


\section{政

especificamente, junto ao princípio da proporcionalidade são os instrumentos com os quais se pode avançar na articulação do sistema de competências comunitárias" ${ }^{80}$.

O Tratado de Lisboa, reconhecendo o princípio da subsidiariedade como princípio essencialmente político, apesar de sua relevância jurídica, submeteu a sua análise primeiramente a instituições políticas, as quais provavelmente discordarão acerca de como a subsidiariedade se aplica em um caso concreto. De fato, não se espera que essas diferentes instituições, principalmente a Comissão e os parlamentos, tenham a mesma opinião, mas que pelo diálogo a observância desse princípio seja aperfeiçoada ${ }^{81}$. Consagrou-se um sistema que coloca o controle da aplicação da subsidiariedade como um controle procedimental, embora o controle jurisdicional não tenha sido eliminado. As instituições legislativas da União Europeia são levadas a realizar um exame detalhado antes de concluírem que a ação no nível europeu é requerida ${ }^{82}$. A solução encontrada para dar efetividade a esse sistema foi integrar os parlamentos nacionais no processo decisório da União Europeia ${ }^{83}$.

\subsection{Redução do déficit democrático}

Frequentemente se atribui à União Europeia um déficit democrático. Essa posição esta associada a um sentimento, o qual por vezes contagia os cidadãos da União, de que a Europa se envolve em assuntos que não deveria, originando uma regulamentação invasora e resultando na impopularidade do processo de integração ${ }^{84}$. Como aduz Jorge Tapia Valdés, a integração traz consigo o risco de afastar ainda mais o cidadão do processo decisório ${ }^{85}$. 0 Sistema de Alerta Precoce alivia esse déficit democrático ao aperfeiçoar o controle dos parlamentos nacionais e também do público em geral sobre o processo legislativo europeu ${ }^{86}$. Sob esse aspecto, o SAP é mais vantajoso do que outros que foram rejeitados: ele é mais democrático do que o controle

\footnotetext{
${ }^{80}$ FERNÁNDEZ FARRERES, Germán. Reflexiones sobre el valor juridico de la doctrina de la subsidiariedad en el derecho administrativo español. NETO, Diogo de Figueiredo Moreira (coord.). Uma avaliação das tendências contemporâneas do direito administrativo. Rio de Janeiro: Renovar, 2003. p. 491-529. p. 525.

${ }^{81}$ COOPER, 2006, p. 294-295.

${ }^{82}$ BERMANN, 1994, p. 331 a 336.

${ }^{83}$ SCHÜTZE, 2009, p. 527 e 528.

${ }^{84}$ ASSEMBLEIA NACIONAL, 2004, p. 10.

85 VALDÉS, Jorge Tapia. Descentralización y subsidiariedad en la época de la globalización. Estudios Constitucionales, Santiago, v. 1, n. 1, p. 99-111, 2003. p. 107.

${ }^{86}$ COOPER, 2006, p.281.
} 


\section{(1)

por um mecanismo técnico ou judicial e menos complicado do que a criação de uma "terceira câmara" legislativa, ao lado do Conselho e do Parlamento Europeu ${ }^{87}$.

Embora o poder de iniciativa legislativa caiba à Comissão, o processo de integração processa-se, em grande medida, por meio de negociações diretas entre os governos nacionais, atrás de portas fechadas, no âmbito de Conselho de Ministros ${ }^{88}$. Esse órgão funciona de forma hermética, não permitindo que a população saiba exatamente o que cada Estado-membro propõe. Espera-se que o Sistema de Alerta Precoce traga mais transparência, pelo envolvimento dos parlamentos, acerca do que é legislado no nível europeu. Espera-se que as propostas dos governos e o funcionamento do Conselho tornem-se mais claros ${ }^{89}$. O SAP permite aos parlamentos nacionais intervir cedo e de forma visível no processo legislativo Europeu, tornando possível mobilizar a opinião pública e influenciar o governo antes que este tenha adotado uma posição oficial sobre o mérito de determinada proposta ${ }^{90}$.

Torna-se importante oportunizar aos parlamentos nacionais participação no processo de controle da aplicação do princípio da subsidiariedade, considerando que estes órgãos estão mais próximos aos seus cidadãos e dispõem consequentemente de um peculiar papel histórico e de legitimidade democrática especial, a qual não pode ser sopesada pelo acréscimo de poder do Parlamento Europeu ${ }^{91}$. Não parece coerente que o controle da aplicação da subsidiariedade caiba exclusivamente aos órgãos do ente mais afastado dos cidadãos. Os parlamentos nacionais são presumivelmente mais sensíveis aos valores atrelados à subsidiariedade e, além disso, ao promoverem o respeito por esse princípio, eles também, por serem eleitos diretamente pelos cidadãos, promovem a legitimidade democrática do processo de integração ${ }^{92}$.

A União Europeia é uma entidade única, pode ser chamada, segundo Alan Dashwood, de ordem constitucional de Estados soberanos: Os Estados mantêm a sua soberania, mas concordam em agir em conjunto, sob arranjos semelhantes aos de uma constituição. É difícil preservar a legitimidade democrática em um ente organizado desta forma. Isso requer um sistema de dupla legitimação. De um lado, há o Parlamento Europeu, que é eleito diretamente, mas é preciso que haja também um controle, a ser exercido pelos parlamentos, sobre a atuação dos ministros do

\footnotetext{
${ }^{87}$ COOPER, 2006, p. 282-283.

${ }^{88}$ COOPER, 2008, p.11-12.

${ }^{89}$ CÂMARA DOS COMUNS, 2008, p. 41.

${ }^{90}$ COOPER, 2008, p.11-12.

${ }^{91}$ COOPER, 2008, p. 2.

92 BERMANN, 2008, p. 455.
} 


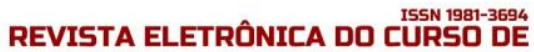

Conselho. O Sistema de Alerta Precoce pode reforçar este segundo aspecto da legitimação do sistema europeu ${ }^{93}$.

Ainda com relação ao déficit democrático enfrentado na União Europeia, uma das questões envolvidas é que os parlamentos nacionais perderam boa parte de seu poder para determinadas instituições da UE. Instituições que, salvo o Parlamento Europeu, não gozam da mesma legitimidade democrática. Algo que fortalece o Sistema de Alerta Precoce é atribuir a proteção das competências dos parlamentos nacionais e a prevenção do uso excessivo das competências comunitárias justamente a eles próprios, órgãos que são os primeiros a perder poder em face da atuação no nível europeu ${ }^{94}$, ou seja, eles defendem um interesse próprio ao monitorarem a subsidiariedade ${ }^{95}$. Mas, obviamente, a consagração do Sistema de Alerta Precoce não terá o poder de compensá-los por toda a perda de poderes sofrida em função da integração ${ }^{96}$, embora a alivie em certa medida ${ }^{97}$. Philipp Kiiver, Universidade de Maastricht, expõe essa questão da seguinte forma:

Em muitos aspectos, as provisões do Tratado aprimorando o papel dos parlamentos nacionais no processo decisório da UE são como uma camada de açúcar ao redor de uma pílula amarga. A pílula é naturalmente o próprio processo de integração europeia, desenvolvida para ajudar o paciente - o cidadão europeu - em formas muito numerosas para serem relatadas. Contudo, nós também saboreamos o gosto amargo da autonomia de decidir os assuntos domésticos esvaindo-se no curso de processos supranacionais. Aqui, os parlamentos nacionais oferecem a solução perfeita: de instituições passivas e marginais, transformá-los em atores ativos do cenário europeu lembra-nos da doçura dos dias quando as leis eram feitas pelo povo e para o povo, em um fórum deliberativo eleito e reconhecível, e no aconchegante contexto do Estado-nação democrático [tradução livre] 98.

Essa redução dos poderes dos parlamentos nacionais não tem, tampouco, sido compensada integralmente por um ganho de poder parlamentar na União Europeia, pois o poder não se deslocou somente em direção ao Parlamento Europeu, mas também em direção ao Conselho, órgão que, embora atue como segunda câmara no sistema legislativo europeu, não é um verdadeiro parlamento e, deste modo, não detém a mesma legitimidade democrática,

\footnotetext{
${ }^{93}$ CÂMARA DOS COMUNS, 2008, p. 39

94 PERNICE, Ingolf. The Treaty of Lisbon: Multilevel Constitutionalism in Action. Columbia Journal of European Law, Nova lorque, v. 15, p. 349-407, 2009. p. 393.

95 SANDER, Florian. Subsidiarity infringements before the European Court of Justice: futile interference with politics or a substantial step towards EU federalism? Columbia Journal Of European Law, Nova lorque, v. 12, p. 517-571, 2006. p. 531.

${ }^{96}$ ROTHENBERGER; VOGT, 2007, p. 16.

${ }^{97}$ COOPER, 2006, p. 291-292.

${ }^{98}$ KIIVER, 2008, p. 77.
} 
considerando-se o seu maior afastamento em relação ao cidadão ${ }^{99}$. De outro lado, mesmo o Parlamento Europeu não dispõe da mesma proximidade em relação aos cidadãos desfrutada pelos parlamentos nacionais, considerando-se as dimensões maiores das circunscrições nas quais são realizadas as eleições para aquele órgão. Por essa razão, os representantes do povo nos parlamentos nacionais estão especialmente bem posicionados para fazer a conexão entre as decisões adotadas em Bruxelas e Estrasburgo e as preocupações dos cidadãos ${ }^{100}$.

Embora no sistema europeu seja responsabilidade dos governos nacionais, por meio de sua atuação no Conselho, assegurar que a soberania nacional não seja restringida excessivamente por medidas da União, eles podem valer-se, contrariando o princípio da subsidiariedade, do procedimento legislativo europeu para aprovar medidas que seriam impopulares no âmbito nacional. Os governos nacionais têm muito menos a perder do que os parlamentos nacionais, porque eles ainda têm um importante papel, através do Conselho de Ministros, no processo decisório europeu ${ }^{101}$. Portanto, acreditamos que enquanto os parlamentos nacionais - e principalmente as minorias parlamentares - tiverem o poder de interferir com o funcionamento do sistema, é provável que o princípio seja considerado mais seriamente ${ }^{102}$. No entanto, devemos ressalvar que a imagem da Comissão e das demais instituições da União Europeia constantemente usurpando os poderes dos Parlamentos nacionais não é a mais correta. Parece haver um consenso entre os parlamentares de que as propostas da Comissão, em sua grande maioria, não são problemáticas em relação ao princípio da subsidiariedade. A Comissão conhece os riscos para o processo de integração que decorreriam dos Parlamentos nacionais criticando publicamente as suas iniciativas por violar o princípio da subsidiariedade, visto o destaque que seria dado a tal fato por setores eurocéticos da mídia ${ }^{103}$.

Por fim, acredita-se que o uso dos novos poderes conferidos aos parlamentos nacionais resultará em um debate político produtivo a respeito das atividades legislativas desenvolvidas no nível europeu. Isso significará um maior envolvimento dos parlamentares, assim como da população dos Estados-membros, na política europeia e, consequentemente, uma maior consciência a respeito das possibilidades que a União oferece, por meio de suas instituições, para a concretização de políticas que estão fora do alcance normal da legislação nacional ${ }^{104}$.

\footnotetext{
${ }^{99}$ COOPER, 2008, p. 2.

100 ASSEMBLEIA NACIONAL, 2004, p.16.

101 COOPER, 2006, p. 292-293.

102 PERNICE, 2009, p. 393.

103 RAUNIO, 2010, p. 6.

104 PERNICE, 2009, p. 393-394.
} 


\section{(1)

Espera-se que o Protocolo $n^{\circ} 2$ estimule os parlamentos nacionais a exercerem um exame mais minucioso do processo legislativo da União Europeia, tornando mais visível para a população os mecanismos de elaboração do Direito Europeu ${ }^{105}$, até mesmo porque causaria constrangimento dos parlamentares frente aos seus eleitores se aqueles não utilizassem as ferramentas que thes foram conferidas para atuar no processo legislativo supranacional ${ }^{106}$.

A consagração do Protocolo relativo à aplicação da subsidiariedade visa incentivar os parlamentos nacionais a exercer o controle da subsidiariedade de forma responsável. Por esse motivo, ao invés de simplesmente manifestar a sua oposição a uma proposta da Comissão, eles devem expressar-se por pareceres "fundamentados", nos quais deverão demonstrar argumentativamente de que forma a proposta em análise viola o princípio da subsidiariedade ${ }^{107}$. Cabe destacar que há uma diferença qualitativa importante entre a manifestação dos governos e a dos parlamentos nacionais, pois estes últimos tendem a atribuir um papel mais relevante à oposição parlamentar, isto é, há um maior espaço para que as diferentes opiniões presentes na sociedade sejam expressas e analisadas, ao contrário do que ocorre quando determinado governo se posiciona, situação em que as diversas opiniões existentes são ocultadas pela opinião oficial do governo ${ }^{108}$.

\section{CONCLUSÃO}

O Sistema de Alerta Precoce favorece o exame das proposições legislativas da Comissão pelos parlamentos nacionais e permite que as preocupações por eles expressadas sejam consideradas de modo mais efetivo pelo Conselho e pelo Parlamento Europeu. Agora a transmissão das propostas ocorre diretamente aos parlamentos nacionais, sem passar por qualquer filtragem pelos governos, garantindo assim um maior tempo para a análise. Pela primeira vez é estabelecida uma ligação direta entre cada parlamento e as instituições da União Europeia. Esse sistema poderá promover uma maior observância do princípio da subsidiariedade, fazendo com que os atos legislativos da União sejam menos frequentes, melhor focados e respeitem mais a autonomia dos Estados-membros. Mas, isso depende da disposição da Comissão em alterar ou retirar as suas propostas em face dos pareceres dos Parlamentos nacionais.

\footnotetext{
${ }^{105}$ CÂMARA DOS LORDES, 2005, p. 23.

${ }^{106}$ KIIVER, 2008, p. 82.

${ }^{107}$ COOPER, 2006, p. 293-294.

${ }^{108}$ FLYNN, 2005. p. 14 e 15.
} 


\section{(1)

A cooperação entre os Parlamentos nacionais e os demais órgãos contribui para a legitimidade democrática da União e aproxima o processo decisório dos cidadãos europeus. 0 objetivo desse sistema é promover o diálogo, o debate e a comunicação institucional, algo que é essencial em qualquer ordem democrática. Para que ele seja eficaz, para que os parlamentos nacionais possam influenciar não apenas os seus governos nacionais, mas também as próprias instituições europeias, é preciso que eles ajam coletivamente, por meio da troca de informações, de comparações das melhores práticas e da coordenação de esforços, pois somente assim será possível atingir o limiar de votos exigido.

O Sistema de Alerta Precoce alivia o déficit democrático europeu ao aperfeiçoar o controle dos Parlamentos nacionais, e desta forma também do público em geral, sobre o processo legislativo. Espera-se que esse sistema traga uma maior transparência, pelo envolvimento dos parlamentos, a respeito do que é legislado no nível europeu. Espera-se que as propostas dos governos e o funcionamento do Conselho tornem-se mais claros. Nesse sentido, algo que fortalece o SAP é atribuir a proteção das competências nacionais e a prevenção do uso excessivo das competências comunitárias justamente aos parlamentos nacionais, órgãos que são os primeiros a perder poder em face da atuação no nível europeu. Considerando a legitimidade democrática que possuem, eles estão na posição mais apropriada para efetivar esta conexão entre a Europa e os seus cidadãos, refletindo as preocupações destes e fazendo com que eles compreendam o projeto europeu e o aceitem.

\section{REFERÊNCIAS}

ASSEMBLEIA NACIONAL. Rapport d'information déposé par la Délégation de l'Assemblée Nationale pour l'Union Européenne sur l'application du principe de subsidiarité. Paris: Presidência da Assembleia Nacional, 2004.

BARACHO, José Alfredo de Oliveira. O Princípio de Subsidiariedade: Conceito e Evolução. Rio de Janeiro: Forense, 1997.

BERMANN, George A. The Lisbon Treaty: The Irish 'No'. National Parliaments and Subsidiarity: An Outsider's View. European Constitutional Law Review, Cambridge, v. 4, p. 453-459, 2008.

BERMANN, George A. Taking Subsidiarity Seriously: Federalism in the European Community and the United States. Columbia Law Review, Nova lorque , v. 94, n. 2, p. 331-456, 1994. 


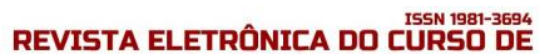

BERNHOLZ, Peter. How to Safeguard Subsidiarity and Competition in the European Union. RMMJournal, Frankfurt, v. 0, p. 327-334, 2009. Disponível em: <http://www.rmmjournal.de/downloads/024_bernholz.pdf>. Acesso em: 4 jan. 2013.

BOURDIN, Delphine; VARA ARRIBAS, Gracia. The Role of Regional Parliaments in the Process of Subsidiarity Analysis within the Early Warning System of the Lisbon Treaty. Bruxelas: Comité das Regiões, 2010. Disponível em:

<http://portal.cor.europa.eu/subsidiarity/SiteCollectionDocuments/Full\%20Regional_parliament s_FINAL.pdf >. Acesso em: 4 jan. 2013.

CÂMARA DOS COMUNS - COMITÊ EUROPEU DE CONTROLE (European Scrutiny Committee). Subsidiarity, National Parliaments and the Lisbon Treaty. 33. relatório da sessão 2007-08. Londres: Câmara dos Comuns, 2008. Disponível em:

<http://www.publications.parliament.uk/pa/cm200708/cmselect/cmeuleg/563/563.pdf>. Acesso em: 4 jan. 2013.

CÂMARA DOS LORDES - COMITÊ DA UNIÃO EUROPEIA. Strengthening national parliamentary scrutiny of the EU - the Constitution's subsidiarity early warning mechanism. 14. relatório da sessão 2004-05. Londres: Câmara dos Lordes, 2005. Disponível em:

<http://www.publications.parliament.uk/pa/ld200405/ldselect/ldeucom/101/101.pdf>. Acesso em: 4 jan. 2013.

CAMPOS, João Mota de. Direito Comunitário. v. 1, 8. ed. Lisboa: Fundação Calouste Gulbenkian, 1997.

CONVENÇÃO EUROPEIA. Conclusões do Grupo de Trabalho I sobre o Princípio da Subsidiariedade. Bruxelas: Convenção Europeia, 2002. Disponível em: <http://register.consilium.europa.eu/pdf/pt/02/cv00/cv00286.pt02.pdf>. Acesso em: 4 jan. 2013.

COOPER, lan. A "Virtual Third Chamber" for the European Union? National Parliaments and Democratic Deliberation in the "Early Warning Mechanism". Eugene, Oregon: All Academic Inc., 2008.

COOPER, Ian. The Watchdogs of Subsidiarity: National Parliaments and the Logic of Arguing in the EU. JCMS: Journal of Common Market Studies, London, v. 44, n. 2, 2006, p. 281-304.

ESTELLA, Antonio. The EU Principle of Subsidiarity and Its Critique. Nova lorque: Oxford University Press, 2002.

FERNÁNDEZ FARRERES, Germán. Reflexiones sobre el valor juridico de la doctrina de la subsidiariedad en el derecho administrativo español. NETO, Diogo de Figueiredo Moreira (coord.). Uma avaliação das tendências contemporâneas do direito administrativo. Rio de Janeiro: Renovar, 2003. p. 491-529.

FLYNN, Brendan. Reformed Subsidiarity in the Constitution for Europe: Can it deliver on expectations? Maastricht: European Institute of Public Administration, 2005. 


\section{政

HORTA, Raul Machado. Federalismo e o Princípio da Subsidiariedade. In: MARTINS, Ives Gandra da Silva (Coord.). As vertentes do direito constitucional contemporâneo. Rio de Janeiro: América jurídica, 2002. p. 461-472.

KIIVER, Philipp. The Treaty of Lisbon, the National Parliaments and the Principle of Subsidiarity. Maastricht Journal of European and Comparative Law, Maastricht, v. 15, p. 77-83, 2008.

PERNICE, Ingolf. The Treaty of Lisbon: Multilevel Constitutionalism in Action. Columbia Journal of European Law, Nova lorque, v. 15, p. 349-407, 2009.

RAUNIO, Tapio. Destined for irrelevance? Subsidiarity control by National Parliaments. Madri: Elcano Royal Institute, 2010. Disponível em:

<http://www.realinstitutoelcano.org/wps/portal/rielcano_eng/Content?WCM_GLOBAL_CONTEXT =/elcano/elcano_in/zonas_in/europe/dt36-2010>. Acesso em: 4 jan. 2013.

ROTHENBERGER, Stefanie; VOGT, Oliver. The "Orange Card": A fitting response to national parliaments' marginalisation in EU decision-making? Berlim: Stiftung Wissenschaft und Politik, 2007. Disponível em: <http://www.swp-

berlin.org/fileadmin/contents/products/projekt_papiere/ipacoo_rothenberger_vogt_ks.pdf>. Acesso em: 4 jan. 2013.

SANDER, Florian. Subsidiarity infringements before the European Court of Justice: futile interference with politics or a substantial step towards EU federalism? Columbia Journal Of European Law, Nova lorque, v. 12, p. 517-571, 2006.

SCHÜTZE, Robert. Subsidiarity after Lisbon: reinforcing the safeguards of federalism. Cambridge Law Journal, Cambridge, v. 68 (3), p. 525-536, nov. 2009.

UNIÃO EUROPEIA. Treaty establishing a Constitution for Europe. Jornal Oficial da União Europeia, n. C 310/1, 16.12.2004.

UNIÃO EUROPEIA. Consolidated versions of the Treaty on European Union and the Treaty on the Functioning of the European Union. Jornal Oficial da União Europeia, n. C 83, 30.03.2010.

VALDÉS, Jorge Tapia. Descentralización y subsidiariedad en la época de la globalización. Estudios Constitucionales, Santiago, v. 1, n. 1, p. 99-111, 2003.

Recebido em: 03 abr. 2013

Revisões requeridas: 01 jul. 2013

Aprovado em: 11 jul. 2013 